\title{
Adoption of open innovation: Evidence from SMEs in the Ghanaian Hospitality Industry
}

\author{
Tian Hongyun ${ }^{1}$, Kankam William Adomako ${ }^{1}$, Florence Appiah-Twum ${ }^{1}$, Isaac Gumah Akolgo ${ }^{1}$, \\ Shuja Iqbal ${ }^{1}$, and Adelaide Spio-Kwofie ${ }^{2}$ \\ ${ }^{1}$ School of Management, Jiangsu University, 301 Xuefu Road, Zhenjiang 212013, Jiangsu, \\ P.R. China. \\ ${ }^{2}$ School of Finance and Economics, Jiangsu University, 301 Xuefu Road, Zhenjiang 212013, \\ Jiangsu, P.R. China.
}

\begin{abstract}
The objective of the study was to analyze the determinants of open innovation adoption among the Ghanaian hospitality SMEs. A cross-sectional survey using a 5-point Likert scale questionnaire was used to randomly collect data from 530 managers within the hospitality industry in Ghana. Using SmartPLS software 3.2.8 to analyze primary data, the results show that all the six determining factors have significant impact on open innovation adoption in the hospitality industry. Specifically, competition, human skills, managerial style and IT infrastructure have positive and significant relationship with open innovation adoption. However, cost and cultural factors had negative but significant influence on open innovation adoption. The study also provides managers with practical ways of adopting open innovation in the Ghanaian hospitality industry.
\end{abstract}

Keywords : open innovation, culture, competition, human skills, cost, IT infrastructure and managerial style

\section{Introduction}

Innovation has become central to firms' survival in a highly challenging hospitality industry (Chen, Hu, \& Yang, 2011). Innovation establishes grounds for competitive edge in the current turbulent business environment (Chen et al., 2011; K.-H. Tsai \& Yang, 2014) and determines the financial and non-financial standing of firms operating in the hospitality industry (Chen et al., 2011). Van der Meer (2007) defined "innovation as the total set of activities leading to the introduction of something new, resulting in strengthening the defendable competitive advantage of a company". On the other hand, open innovation according to Henry Chesbrough (2003) is a "paradigm that assumes that firms can and should use external ideas as well as internal ideas, and internal and external paths to market, as the firms look to advance their technology".

West and Gallagher (2006) defined "open innovation as a set of practices for profiting from innovation and a cognitive model for creating, interpreting and researching those practices". The term open innovation is a relatively newer concept commonly referred to as the use of purposive inflows and outflows of knowledge to accelerate internal innovation, and expand the markets for external use of innovation, respectively (Henry Chesbrough, Vanhaverbeke, \& West, 2006). This philosophy assumes that firms can and should use external ideas as well as internal ideas, and internal and external paths to market, as they look to advance their technology (Henry Chesbrough et al., 2006). On their part, West and Gallagher (2006) see open innovation as "systematically encouraging and exploring a wide range of internal and external sources for innovation opportunities, consciously integrating that exploration with firms' capabilities and resources and broadly exploiting those opportunities through multiple channels". 
Inauen and Schenker-Wicki (2012) analyzed the influence of inside-out open innovation and found that companies that put emphasis on inside-out open innovation are more likely to create radical innovations and tend to sell a greater number of new products. Open innovation has generated high interest among academics and practitioners over the last two decades. There is a large volume of published studies describing the role of open innovation which generally professed that firms should innovate to be effective, or even to survive, and that research can guide the management of innovation in organizations. "As knowledge becomes the key resource, open innovation needs to be embedded in an overall business strategy that explicitly acknowledges the potential use of external ideas, knowledge and technology in value creation" (OECD, 2008 ).

Despite the growing body of knowledge, there is still poor evidence of the determining factors of open innovation in the hospitality industry (Page \& Schirr, 2008). Hospitality SMEs in Ghana can have a breakthrough in terms of success by opening up to external inflows of ideas, knowledge and resources. Open innovation has generated high interest among academicians and practitioners over the last two decades, there is no evidence that hospitality SMEs are adopting open innovation (Storey, Keasey, Watson, \& Wynarczyk, 2016). Moreover, Biemans and Griffin (2018) concluded that in spite of the growth of studies about open innovation, scholars have criticized the lack of attention paid to determining factors in the adoption of open innovation in the hospitality industry.

Comparing new product innovation, service innovation is fragmented and does not provide managers with a set of generally accepted factors influencing the adoption of open innovation in the hospitality SMEs (Biemans \& Griffin, 2018). This study seeks to analyze the determinants of open innovation adoption among the Ghanaian hospitality SMEs.

\section{Overview of SMEs Sub-Sector}

Traditionally, it has been argued that small and medium scale enterprises (SMEs) are key indispensable elements of most economies in the world. According to OECD (2017), SMEs are the firms, employing up to 249 persons, with the following breakdown: micro (1 to 9), small (10 to 49) and medium (50-249). Similarly, Ghana Statistical Service ( 2013), argues that firms with fewer than ten (10) employees are small-scale enterprises and their counterparts with more than ten (10) employees are medium and large-sized enterprises. OECD (2017), contends that, SMEs account for approximately $99 \%$ of all firms, accounting for about $70 \%$ of jobs and very much integral to value creation, generating between $50 \%$ and $60 \%$ of value added on average. In Europe, SMEs account for $99 \%$ of non-financial businesses, which provide about $70 \%$ of employment opportunities (Nieto \& Santamaría, 2010).

Abor and Quartey (2010) have noted that SMEs in Ghana constitute 85\% of the manufacturing sector's employment. They are also believed to contribute about $70 \%$ to Ghana's GDP and account for about $92 \%$ of businesses in Ghana. Notwithstanding the recognition of the important roles SMEs play, their development is largely constrained by a number of factors, such as lack of access to appropriate technology; limited access to international markets; the existence of laws; regulations and rules that impede the development of the sector; weak institutional capacity; lack of management skills and training; and most importantly, access to finance.

\section{Ghanaian Hospitality Industry}

Ghana's economy benefits significantly from tourism. The tourism sector is a major foreign exchange earner at the third position in Ghana and contributes hugely to Ghana's GDP, creating jobs in the process (Ghana Tourism Authority, 2010). Tourism is one of a relevant service sector in Ghana, although it is an immature and growing industry in the country. The conventional earners of foreign exchange in Ghana are the cocoa, timber and gold. Nevertheless, Ghana has overcome over reliance on these conventional minerals and commodities and redirected focus on tourism, building on its potential to become a leading foreign exchange earner. Currently, tourism sector is fourth highest foreigner exchange earner in Ghana (Jumia Travel, 2019 ).

The tourism industry holds the potential to help in the economic growth of Ghana as demonstrated in the industry's potential to create job and generate income. This is to say that the tourism sector has demonstrated as much, its significant contribution to GDP, foreign exchange earnings, employment and 
export diversification as well as private sector investment. The travel and tour contributed directly to GDP by GHC 4.9 million equivalent to USD 1.2 million, representing 3\% of GDP. It is also expected to increase by $5.6 \%$, which is GHC 5.2 million, equal to USD 1.2 million and by $5.1 \%$ per year to GHC 8.6 million, also making USD 2 million, representing 2.9\% of GDP in 2017 and by 2027 respectively (Ghana Tourism Authority, 2016). In 2016, about 288,000 jobs were directly created, which was a $2.4 \%$ rise from overall employment of $2.6 \%$ in 2015 (Ghana Tourism Authority, 2016). It is also expected to increase by $4.1 \%$ annually. It is also forecasted that by 2027 , there should be an increase of $4.1 \%$ annually in international tourist arrival. Expected revenue is GHC 5.9 Million, which is about USD 1.4 Million. Direct Travel and Tourism GDP of $56.7 \%$ was generated through domestic travel spending. Recent work by Oxford Business Group (2019) has established that, tourism contributed GHS12.58bn (\$2.7bn), or 6.2\%, to national GDP in the year ending 2017. In the same year a total of $1.3 \mathrm{~m}$ international tourists visited the country that same year, representing a $6 \%$ increase compared to 2016 . At the end of 2017 , the sector provided 682,000 jobs, or $5.3 \%$ of total national employment (Oxford Business Group, 2019). A rise of 5.3\% is also expected per year estimated closely to GHC 8.7 million (\$2M) by 2027 (Jumia Travel, 2019 ).

The driving forces behind the Ghanaian hospitality industry are its rich cultural heritage, flamboyant carnivals and primeval beaches, historic slave forts and castles, enticing sultry weather, green shrubbery, as well as wild life, and, above all its hospitable people (Mensah, 2006). Hotels have in recent times increased dramatically and the Ghana Tourism Authority (2016) reports that, about 2969 hotels have been set up and licensed. These hotels are classified into star-rated, inns and budget hotels. Overall, the star-rated hotels number up to 680 and break shows; 3 Five-Star Hotels, 39 Three-Star Hotels and 12 Four-Star Hotels. The Inns are about 170 and the budget hotels are up to 2119 in total (Xuhua, Spio-Kwofie, Udimal, \& Addai, 2018). Currently, the investment rate in the hotel sector in Ghana is seemingly focused on available business opportunities in this area (Narteh, Agbemabiese, Kodua, \& Braimah, 2013).

International trademarks such as Best Western, Mövenpick Ambassador as well as Holiday Inn all have come to settle strongly in the hotel sector of Ghana. The coming in of these key international players and the many high-rated star hotels has resulted in a more intense competition in the sector (Narteh et al., 2013). Hotels have increased in every corner, nooks and cranny of the hotel just to be able to meet the lodging demands in Ghana.

\section{Literature Review and Hypotheses development}

\section{Figure 1}

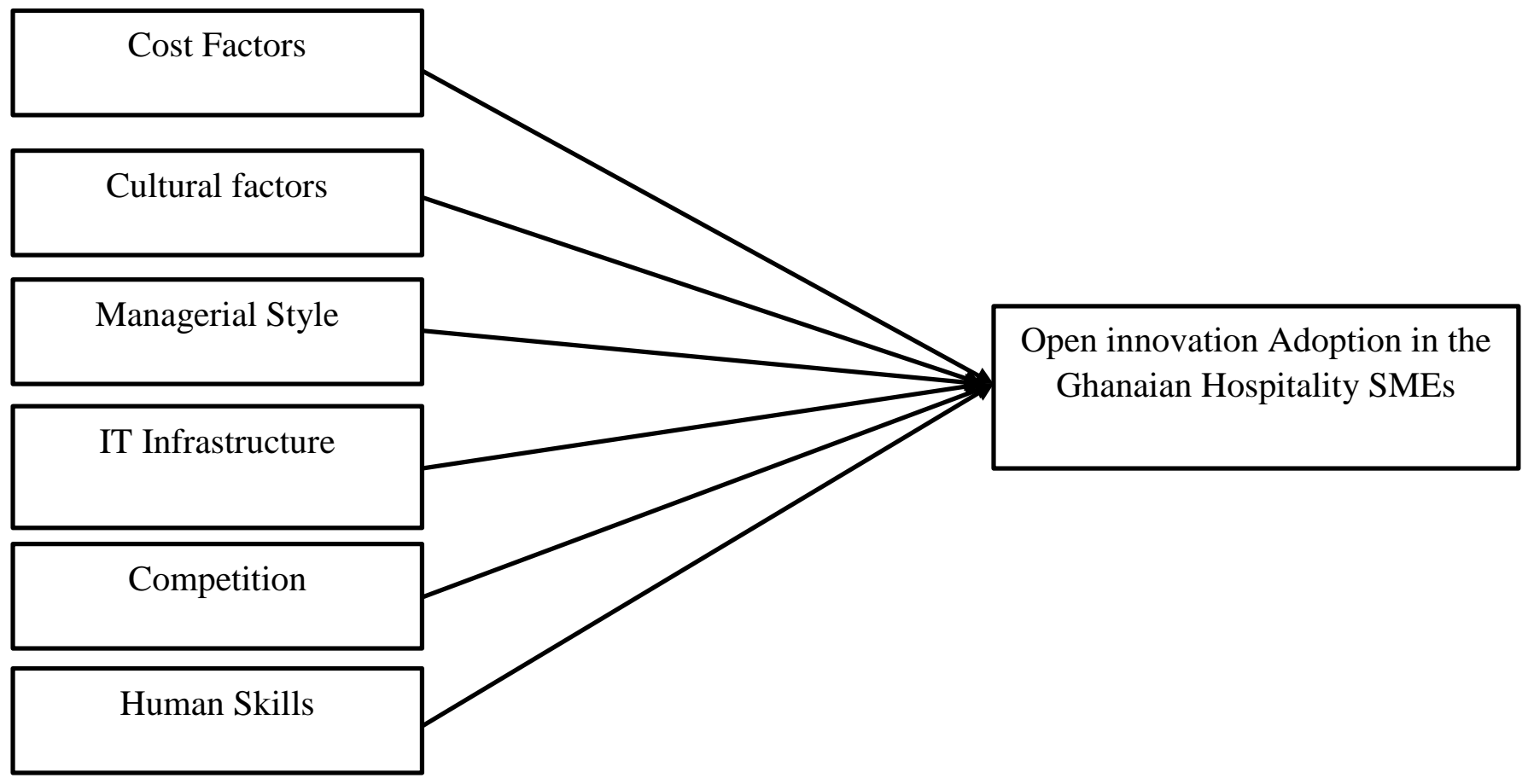




\section{Relationship between Cost Factors and open innovation}

Cost factors in this study refer to the resources at the disposal of SMEs. Previous studies have reported that one central issue fronting SMEs in their quest to innovate is the lack of resources (Abor \& Quartey, 2010; OECD, 2017). The cost of doing business is increasing day-in-day out with number of taxes, becoming quite uncomfortable for most SMEs (World Bank, 2018). There is some evidence to suggest that SMEs operating in the hospitality sector are not competitive due to lack of coordination, high costs of doing business, relatively high transaction costs, low capacities, and difficult access to finance, and a high-risk perception for investing in the sector (World Bank, 2018). Researchers are, however, conscious of the implication of getting sufficient resources and its effect on firms' innovation strategies and policies. A number of researchers have reported that firms can meaningfully succeed depending on their innovative efforts and the quality of its capital stock (Abor \& Quartey, 2010; Santarelli \& Sterlacchini, 1990). Kerr and Newell (2003) point out that technology adoption significantly hangs on the amount of planned capital expenditure and the firm's ability to secure capital for technology adoption. However, capital is expected to offer the needed prospects for technology adoption activities in the firm, cost of capital is a key issue that thwarts the firm's ability to make technology investment decisions (Kerr \& Newell, 2003).

H1: Cost factors have significant inverse effect on adoption of open innovation in the hospitality SMEs in Ghana

\section{The relationship between IT infrastructure and open innovation adoption}

Information and Communication Technologies (ICT) consist of the hardware, software, networks and media for the collection, storage, processing, transmission and presentation of information (voice, data, text, images), as well as related services (OECD, 2015). According to Gerguri and Ramadani (2010) "Innovation is a process of transforming the new ideas, new knowledge into new products and services. Joseph Schumpeter defines innovation as an activity which leads to new producing function, new product". "Innovations represent a process, namely an activity of creating a new product or service, new technologic process, new organization, or enhancement of existing product or service, existing technologic process and existing organization" (Gerguri \& Ramadani, 2010). In a similar fashion, Lichtenthaler (2011), defines open innovation as systematically performing knowledge exploration, retention, and exploitation inside and outside an organization's boundaries throughout the innovation process. Innovation has become a crucial element of survival for firms within every industry due to the crucial changes that are affecting modern economies. Hospitality SMEs have been urged to identify the essential resources that can possibly create a competitive edge in the current business environment. According to Mihalic and Buhalis (2013), hospitality SMEs should also discover how they can access and take advantage of these resources in order to enhance their performance in the current turbulent business environment. The extant literature has emphasized the importance of Information technology (IT) for example Internet, central reservations systems (CRS) and other electronic distribution systems can be seen as a pretty new competitive resource (Mihalic \& Buhalis, 2013). In recent years, scholars have argued that ICT and Internet can generate competitive advantage and augment firm performance (Namasivayam, Enz, \& Siguaw, 2000; Porter, Michael, \& Gibbs, 2001; Sirirak, Islam, Ba Khang, \& Technology, 2011). To H. Tsai, Song, and Wong (2009) investing in ICT infrastructure is a means to improve firm performance, especially in the hotel industry. In more tangible terms, study findings point to the fact that firms in the hospitality sectors need to speed the ICT implementation (Mihalic \& Buhalis, 2013). ICT is a supporter of innovation (open and close) in the hospitality industry (Mihalic \& Buhalis, 2013). Kankam (2015) argues that ICT is one of the many factors that have influenced users' adoption of Social Networking as a communication tool. Thus, ICT infrastructure influence the adoption of open innovation in the hospitality industry (Kankam, 2015). In recent years, studies on innovation have paid particular attention to the connection between ICT and new product development. More often than not, large companies have the capacity to engage in $R \& D$ and hence able to adopt new technologies (open innovation). Prior research have found positive relationship between firm size and the speed of innovation adoption. The role of Information and Communication Technologies (ICT) has been emphasized hugely to increase the ability of firms to work across diverse geographic and organizational boundaries (Pavitt, 2003). Similarly, Christensen and Maskell (2003) contend that ICT has helped to support the shift toward more open, collaborative and network-centered innovation practices. Hence, ICT infrastructure facilitates the adoption of open innovation in the hospitality industry. Faems, De Visser, Andries, and Van Looy (2010) found that 
technology alliance portfolio diversity has a positive impact on internal innovation efforts, which increases product innovation performance.

\section{H2: ICT infrastructure has significant relationship with open innovation adoption in the hospitality industry}

\section{Relationship between management/leadership style and open innovation adoption}

There is an unambiguous relationship between leadership and innovation (Denti \& Hemlin, 2012; Närvänen, 2018). According to Mumford, Antes, Caughron, and Friedrich (2008) management plays a pivotal role in enhancing firms' creativity, Bossink (2007) contends that launching and driving innovation projects depends on leadership, and implementing innovation schemes and overcoming opposition (Gilley, Dixon, \& Gilley, 2008). Yukl and Mahsud (2010) posits that leadership "involves a process whereby intentional influence is exerted over other people to guide, structure, and facilitate activities and relationships in a group or organization." The capacity to inspire a group go along with the ability to motivate and "enable employees to contribute to the success of the organization". Innovative leaders and friendly working environment have the potential to create and develop oriented attributes of organizational workforce (Becan, Knight, \& Flynn, 2012). Becan et al. (2012) found an overflow effect of leaders' backing of innovative thinking and action causing workforces to strengthen their own adaptive skills and carrying this innovative thinking into individual adoption. According to Simpson and Dansereau (2007) adoption of innovation depends heavily on management and leadership styles, employee empowerment and organizational climate that promotes innovation (open and close). Becan et al. (2012) studied the innovation adoption as facilitated by a changeoriented workplace found that the tendency to adopt workshop-based interventions is contingent on innovative firm with creative leadership and change-oriented workforce attributes such as professional growth, efficacy, adaptability and influence on others. On their part, Scherp, Pscheida, et al. (2017) stated that leadership is required for opening the innovation process and fostering open innovation continuously beyond the phase of its introduction. Moreover, using a sample of Korean SMEs, Ahn, Minshall, and Mortara (2017) showed that CEOs' characteristics, namely, positive attitude, entrepreneurial orientation, patience and education, can play important role in facilitating open innovation. Similarly, Elenkov, Judge, and Wright (2005) concluded that leadership can be supportive to achieve organizational innovations.

H3: management and leadership style has positive and significant relationship with the adoption of open innovation in the hospitality industry

\section{Relationship between culture and open innovation adoption}

Culture refers to the "collective programming of the mind that distinguishes the members in one group or category of people from another" (Hofstede, 2001). Schein (1992) defined culture pertaining to an organization as the fundamental beliefs, assumptions, values and ways of interacting that contribute to the unique social and psychological environment of an organization. Prior research has reported that existing cultural norms highly influenced the adoption of innovation (Herbig \& Dunphy, 1998; Scherp, Mezaris, Köhler, \& Hauptmann, 2017). Thus, technology adoption is influenced by cultural differences. Eseonu and Egbue (2014) are of the view that culture influences attitudes and behavioral intention towards technology and innovation, which have been shown to affect decision to adopt technology. Herzog (2011) contends that open and closed innovation paradigms are different and management must lead the way to the risk taking culture that favors open innovation. Recently investigators have examined the effects of culture on innovation.

In their systematic literature review of the studies that have analyzed the impact of culture on innovation. Tian, Deng, Zhang, and Salmador (2018) discuss how a variety of culturally related factors combine to facilitate or restrict innovation performance in their corresponding cluster. According to Tian et al. (2018) there is complex and idiosyncratic relationship between culture and innovation. Shane (1993) suggests that nations may differ in their rates of innovation because of the cultural values of their citizens. Mazur and Zaborek (2016) examined the links between organizational culture, the use of open innovation sources and the performance of SMEs and found a positive association between innovative culture and the scope of open sources of innovation. Franzo (2017) concluded that highly integrative culture relates positively to in-bound open innovation. Other researchers, however, looked at the relationship between culture and innovation and have found negative relationship, for example, Kaasa and Vadi (2010) found negative relationship between 
culture and innovation. Yaveroglu and Donthu (2002) found a negative relationship between power distance and consumers' intention to innovate in a study that set to determine diffusion of consumer products in 19 wealthier nations. Again, Mitchell, Smith, Seawright, and Morse (2000) suggest that a high power distance as a cultural dimension has a negative effect on business creation processes.

On their part, Williams and McGuire (2005) showed that uncertainty avoidance has a negative effect on the economic creativity of a country. Autio, Pathak, and Wennberg (2013), in their empirical study on cultural practices and their relationship to the initiative and entrepreneurial growth, based on the Global Entrepreneurship Monitor (GEM) and Global Leadership and Organizational Behavior Effectiveness (GLOBE), found that cultural practices of uncertainty avoidance are negatively associated with entrepreneurship.

H4: cultural factors have negative and significant relationship with open innovation adoption in the hospitality industry

\section{The relationship between competition and open innovation adoption}

Commenting on competition, Nguyen, Van Ness, and Van Ness (2007) and Santamaría, Nieto, and Miles (2012) argue that a significant factor for a firm's innovation adoption is the outside cooperation effect of firms with competitors. Overall, there seems to be some evidence to indicate that, competitors play significant roles in the adoption of open innovation (Nicita, Ramello, \& Scherer, 2005).

On their part, Henry Chesbrough and Crowther (2006), postulate that firms interact with competitors for idea generation and technology. Van der Meer (2007) and West and Gallagher (2006) customers play a key role to induce the adoption of open innovation. Prior studies such as Nickell (1996) and Blundell, Griffith, and Van Reenen (1999) both find a positive linear effect of competition on innovation. Moen, Tvedten, and Wold (2018) explore the relationship between innovation and competition in 380 Norwegian SMEs and found competition to have positive correlation with innovation.

H5: Competition has positive and significant effect on open innovation adoption

\section{Relationship between human skills and open innovation adoption}

Zhang et al. (2012) postulated that human resources management practices have a direct effect on the adoption of innovation practices within a firm especially when they are combined with "the decentralization of decision making, delegation and knowledge sharing and various pecuniary and non-pecuniary incentives". Becan et al. (2012) studied the innovation adoption as facilitated by a change-oriented workplace found that the tendency to adopt workshop-based interventions is contingent on innovative firm with creative leadership and change-oriented workforce attributes such as professional growth, efficacy, adaptability and influence on others. Prior studies that have noted the importance of implementing human resource strategies that can inspire innovation performance of firms (Atuahene-Gima, 1996; Laursen \& Foss, 2003).

Bogers, Foss, and Lyngsie (2018) suggest that firms with a diverse human capital pool have competitive edge in terms of engaging in open innovation. Surveys such as that conducted by Ahn et al. (2017), concluded that a paradigm shift from a closed to an open innovation process requires certain leadership traits and personal skills. In a similar fashion, Lindegaard (2010) shows that open innovation adoption calls for certain personal skills such as optimism, passion, drive, curiosity and the belief that change can be good. Hence, human skills in the adoption of open innovation is crucial because innovation process is spearheaded by people (Ahn et al., 2017), as human factors such as user adaptation, acceptance, training, and on-going support are as critical as the technical aspects of the implementation process (Delone \& McLean, 2003). Delone and McLean (2003) posit that the success of implementing innovation is predicated on human resource factors.

H6: Human skills have positive and significant relationship with open innovation adoption in the hospitality industry

\section{Methodology}

The purpose of the study was to analyze the determining factors of open innovation adoption in the Ghanaian hospitality industry. To achieve this objective, the study employed the survey research method in 
the data collection process. Survey has been the dominant methodology in entrepreneurial research (Das, 2009). The empirical part was conducted in Ghana. Statistics on hospitality SMEs show an upward surge in the number of hospitality businesses (Xuhua et al., 2018). According to Ghana Tourism Authority (2016), there are 2969 licensed hotels in Ghana ranging from star-rated, guesthouses and budget hotels.

A total of 700 hotels across the country with valid contact addresses were obtained and randomly selected and contacted by telephone to elicit their participation in the study. The hotels selected were those that met the following requirement. According to Adomako (2018), hotels with more than 5 employees and a maximum of 250 employees (Ghana Statistical Service, 2013), companies that were owned and controlled by individual (or a team of) entrepreneurs with majority ownership (Goedhuys \& Sleuwaegen, 2010), and firms with a minimum of five years' operating experience (Morgan, Leech, Gloeckner, \& Barrett, 2004). The questionnaire was the data collection tool. The questions were developed on a 5-point Likert scale ranging from 5 (strongly agree) to 1 (strongly disagree). 678 firms eventually responded to the questionnaire administered by local research firm with highly trained researchers (Boso, Story, \& Cadogan, 2013; Hinson \& Sorensen, 2006). Questionnaires were then sent to these hotels and were filled by managers whose work was related to operations, innovation and/or business development. Manual (2005) states that managers are ideal respondents for innovation surveys in small firms. We took inspiration from Manual (2005), and conducted a surveyed middle and top managers working in Ghanaian hospitality SMEs. Middle managers and top managers were chosen because of their know-how of the strategic direction of their firms. 530 complete responses were received and were subsequently used in the study. The participating hospitality SMEs (Hotels) can be broken down into the following proportions per category: 5 star (6\%), 4 star (9\%), 3 star (27\%), 2 star (23\%), 1 star (17\%), budget hotel (10\%) and guest house (8\%).

\section{Variables and measures}

The constructs of interest in this research were (competition, cost factors, cultural factors, managerial style, human skills and IT infrastructure). Regarding measures, the items for cost factors were adapted from (Statistics Norway, 2012), the items for cultural factors were also adapted from literature (Naqshbandi, Kaur, \& Ma, 2015), we relied on the items developed by Orosz et al. (2018) to measure competition, the items for IT infrastructure were adopted from (OECD, 2015), while human skills was measured using established scales proposed by (Zopiatis \& Theocharous, 2018) and to measure openness, measuring scales were derived from previous literature by (Yun, Park, Kim, \& Yang, 2016). Finally, we adapted the scale developed by Swart (2013) to measure managerial style.

\section{Figure 2 Research Model}

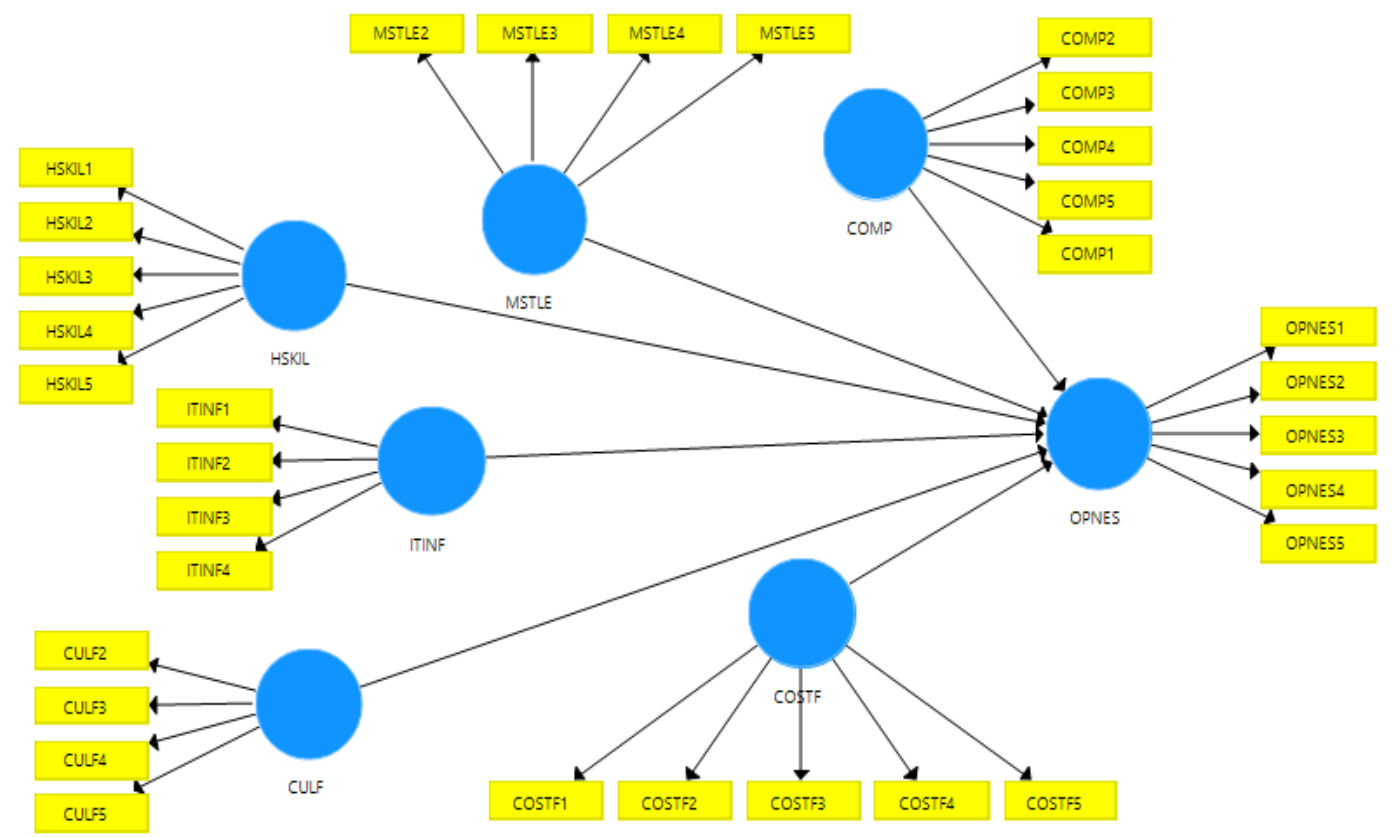




\section{Analysis}

For this study, it was of interest to test the hypothesized relationships among the constructs (competition, cost factors, cultural factors, human skills, IT infrastructure and managerial style) by using partial least squares (PLS) with SmartPLS software 3.2.8 (Ringle, Wende, \& Becker, 2015). According to (Haenlein \& Kaplan, 2004), the primary benefits of structural equation analysis far outweigh the old-fashioned multivariate analysis. (Falk \& Miller, 1992), argued that PLS is flexible in terms of maintaining minimum requirements on the sample, assessing the scale items, and the distribution of observable variables; also, it does not need the normality of the data and is more suitable for small and large samples. Wong (2013), points out that PLS path modeling is a standard algorithm which first evaluates the measurement model including internal consistency, convergent validity, and discriminant validity. The next phase comprises the estimation of the structural model and requires testing collinearity among constructs, and assessing the significance and relevant relationships.

\section{Measurement (outer) Model}

PLS bootstrapping technique was used to estimate all the constructs. The threshold recommended by Hair Jr, Sarstedt, Hopkins, and Kuppelwieser (2014) to determine the significance of factor loadings was followed ( 0.5 or greater).

The minimum acceptable threshold for composite reliability is 0.7 (Hulland, 1999) and 0.4 for average variance extracted (Magner, Welker, \& Campbell, 1996). Table 1 summarizes results for the items loadings.

\section{Table I: Measurement Model Analysis}

\begin{tabular}{|c|c|c|}
\hline Constructs & Items & Loadings \\
\hline \multirow[t]{5}{*}{ HSKIL } & HSKIL1 & 0.897 \\
\hline & HSKIL2 & 0.857 \\
\hline & HSKIL3 & 0.919 \\
\hline & HSKIL4 & 0.848 \\
\hline & HSKIL5 & 0.877 \\
\hline \multirow[t]{4}{*}{ MSTLE } & MSTLE2 & 0.860 \\
\hline & MSTLE3 & 0.867 \\
\hline & MSTLE4 & 0.875 \\
\hline & MSTLE5 & 0.853 \\
\hline \multirow[t]{5}{*}{ COMP } & COMP1 & 0.740 \\
\hline & COMP2 & 0.890 \\
\hline & COMP3 & 0.912 \\
\hline & COMP4 & 0.901 \\
\hline & COMP5 & 0.820 \\
\hline \multirow[t]{4}{*}{ ITINF } & ITINF1 & 0.897 \\
\hline & ITINF2 & 0.880 \\
\hline & ITINF3 & 0.898 \\
\hline & ITINF4 & 0.829 \\
\hline \multirow[t]{4}{*}{ CULF } & CULF2 & 0.780 \\
\hline & CULF3 & 0.883 \\
\hline & CULF4 & 0.914 \\
\hline & CULF5 & 0.906 \\
\hline \multirow[t]{5}{*}{ COSTF } & COSTF1 & 0.743 \\
\hline & COSTF2 & 0.714 \\
\hline & COSTF3 & 0.885 \\
\hline & COSTF4 & 0.873 \\
\hline & COSTF5 & 0.803 \\
\hline OPNES & OPNES1 & 0.851 \\
\hline
\end{tabular}




\begin{tabular}{|l|l|l|}
\hline & OPNES2 & 0.814 \\
\hline & OPNES3 3 & 0.895 \\
\hline & OPNES4 & 0.892 \\
\hline & OPNES5 & 0.811 \\
\hline
\end{tabular}

As seen in Table 2. The composite reliability coefficients of the constructs ranged from 0.902 and 0.945 , and Cronbach's alpha (CA) ranged from 0.867 to 0.927 . These thresholds exceed the minimum standard level of 0.70 , hence internal consistency reliability is achieved. The AVE values exceed the threshold of 0.5 (Hair $\mathrm{Jr}$ et al., 2014). Again, the VIF values are clearly below the threshold of 5, which indicates that collinearity does not reach critical levels in any of the constructs (Hair, Ringle, \& Sarstedt, 2011).

Table II: Tests of Construct Reliability and Validity

\begin{tabular}{|l|l|l|l|l|l|}
\hline Constructs & Cronbach alpha & Composite reliability & AVE & $\mathrm{R}^{2}$ & VIF \\
\hline HSKIL & 0.927 & 0.945 & 0.774 & & 2.749 \\
\hline MSTLE & 0.887 & 0.922 & 0.746 & & 2.611 \\
\hline COMP & 0.906 & 0.931 & 0.731 & & 1.658 \\
\hline ITINF & 0.899 & 0.930 & 0.768 & & 2.170 \\
\hline CULF & 0.894 & 0.927 & 0.761 & & 1.642 \\
\hline COSTF & 0.867 & 0.902 & 0.650 & & 1.733 \\
\hline OPNES & 0.922 & 0.941 & 0.763 & 0.987 & 2.304 \\
\hline
\end{tabular}

The results presented in the correlation matrix in Table 3 include correlations between constructs in the offdiagonal cells and the square root of AVE in the diagonal cells. For adequate discriminant validity, the diagonal values should be significantly greater than the off-diagonal values in the corresponding rows and columns. The diagonal values (the square root of AVE) in Table 3 are all greater than their respective offdiagonal values, indicating adequate discriminant validity. In other words, for each construct, the root of the AVE measures is significantly larger than the latent variable correlation. This demonstrates that, the final revised measurement model for all the constructs had adequate discriminant validity.

Table III: Discriminant Validity

\begin{tabular}{|l|l|l|l|l|l|l|l|}
\hline & COMP & COSTF & CULF & HSKIL & ITINF & MSTLE & OPNES \\
\hline COMP & $\mathbf{0 . 8 5 5}$ & & & & & & \\
\hline COSTF & 0.786 & $\mathbf{0 . 8 0 6}$ & & & & & \\
\hline CULF & 0.561 & 0.750 & $\mathbf{0 . 8 7 2}$ & & & & \\
\hline HSKIL & 0.609 & 0.818 & 0.610 & $\mathbf{0 . 8 8 0}$ & & & \\
\hline ITINF & 0.577 & 0.776 & 0.576 & 0.801 & $\mathbf{0 . 8 7 6}$ & & \\
\hline MSTLE & 0.656 & 0.866 & 0.641 & 0.869 & 0.716 & $\mathbf{0 . 8 6 4}$ & \\
\hline OPNES & 0.607 & 0.820 & 0.602 & 0.890 & 0.748 & 0.898 & $\mathbf{0 . 8 7 3}$ \\
\hline
\end{tabular}


The test of the structural model includes estimating the path coefficients, $t$-statistics and $\mathrm{R}^{2}$. These statistics evaluate the proportion of the variance in the endogenous variable that can be explained by the exogenous variables. The bootstrapping technique was employed to test for the effects of social capital on performance.

In addition, all the variables were modeled as reflective measures, since they were believed to influence the dependent variable, which, in this research, was open innovation. Figure 2 demonstrates the PLS graph of the relationships between the variables (competition, cost factors, cultural factors, human skills, managerial style and IT infrastructure). The path coefficients and significant levels for the various relationships are discussed in the subsequent paragraphs.

\section{Figure II Measurement Model Results}

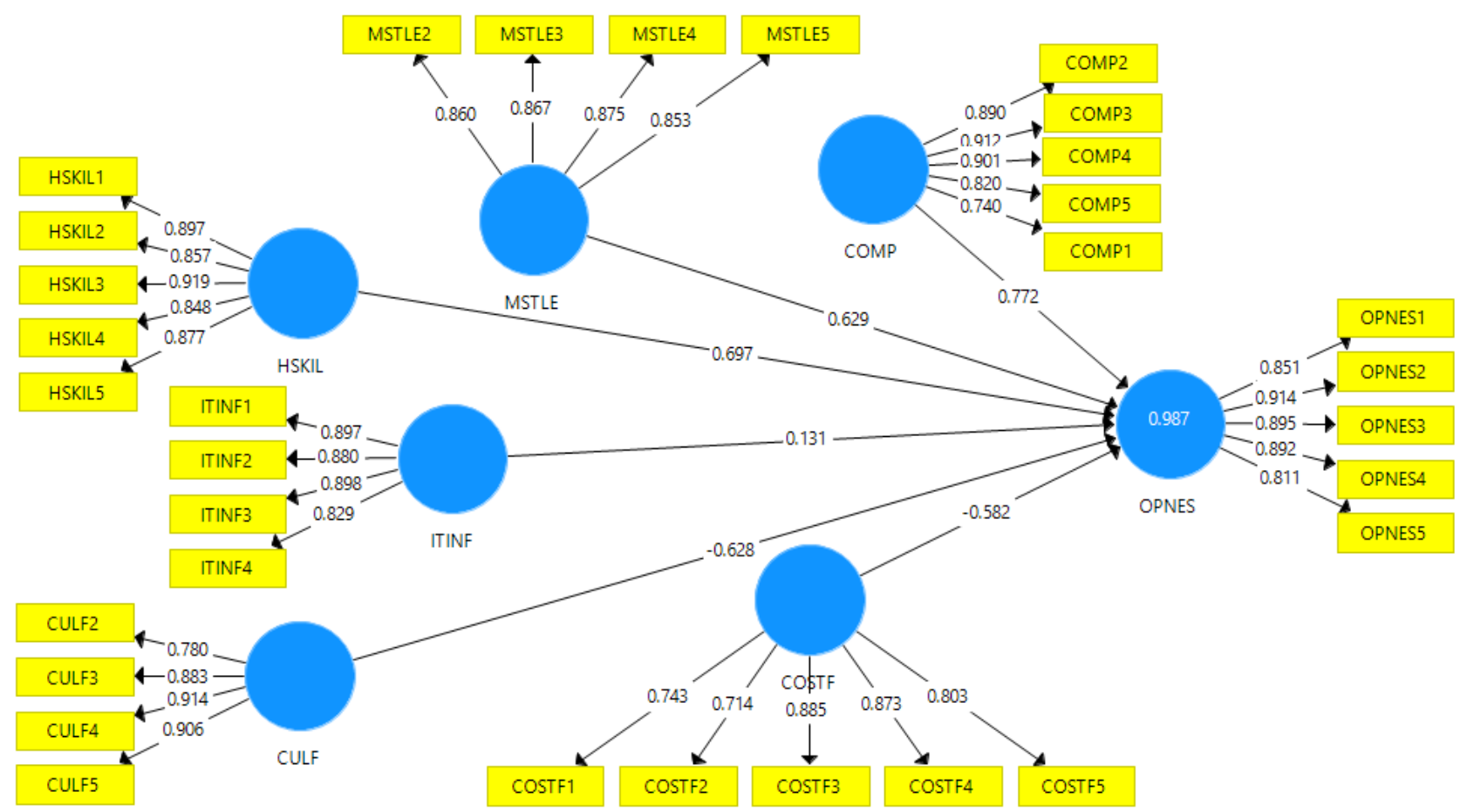

\subsection{Testing of hypothesis}

The study sought to analyze the determinants of open innovation adoption among the Ghanaian hospitality SMEs. As shown in Fig. II and Table IV, open innovation was used as the dependent variable whereas the determining factors of open innovation were used as independent variables. The results revealed that competition has a statistically significant relationship with open innovation adoption $(\beta=0.772, t$-value $=11.301, \rho<0.000$ ). Regarding cost factors, we found negative but statistically significant relationship between cost factors and open innovation adoption $(\beta=-0.589, t$-value $=17.503, \rho<0.000)$. On cultural factors, the study found negative but statistically significant relationship between culture and open innovation adoption $(\beta=-0.628, t$-value $=10.699, \rho<0.000)$. The results also revealed that there was a significant positive relationship between human skills and open innovation adoption $(\beta=0.697, t$-value $=14.170, \rho<0.000$ ). IT infrastructure is found to have direct and positive relationship with open innovation adoption $(\beta=0.131, t$-value $=2.721, \rho<0.007)$. Similarly, managerial style was found to positively influence open innovation adoption $(\beta=0.629, t$-value $=19.567, \rho<0.000)$. 
Table IV. Structural Model Results

\begin{tabular}{|l|c|c|c|c|c|}
\hline Hypotheses & $\begin{array}{c}\text { Original Sample } \\
(\mathrm{O})\end{array}$ & $\begin{array}{c}\text { Sample Mean } \\
(\mathrm{M})\end{array}$ & Standard Deviation & T-Statistics & P-Value \\
\hline COMP -> OPNES & 0.772 & 0.771 & 0.068 & 11.301 & 0.000 \\
\hline COSTF -> OPNES & -0.582 & -0.579 & 0.033 & 17.503 & 0.000 \\
\hline CULF -> OPNES & -0.628 & -0.627 & 0.059 & 10.699 & 0.000 \\
\hline HSKIL -> OPNES & 0.697 & 0.695 & 0.049 & 14.170 & 0.000 \\
\hline ITINF -> OPNES & 0.131 & 0.133 & 0.048 & 2.721 & 0.007 \\
\hline MSTLE -> OPNES & 0.629 & 0.627 & 0.032 & 19.567 & 0.000 \\
\hline
\end{tabular}

\subsection{Discussion of study results}

This paper investigates the factors determining open innovation adoption in the Ghanaian hospitality industry. Open innovation is an emerging concept that has recently attracted a lot of attention, both in practice and in academia. Six determining factors of open innovation were identified through a comprehensive review of the extant literature and their influence on open innovation adoption was investigated in the Ghanaian hospitality industry. From the study, all the six hypothesized relationships were confirmed and the study provided hospitality SME managers with different factors that could facilitate open innovation adoption.

In terms of the relative importance of the independent variables to open innovation adoption, past empirical studies have shown that competition has a strong relationship with open innovation adoption $(\beta=0.772, t$ value $=11.301, \rho<0.000$ ). The finding is consistent with previous studies by Nguyen et al. (2007) who argues that a significant factor for a firm's innovation adoption is the outside cooperation effect of firms with competitors. Similarly, the result confirms the findings of Nickell (1996) and Blundell et al. (1999) who found a positive linear effect of competition on innovation. Thus in support with prior studies, this study strengthens the consideration given to competition as a key determinant of open innovation adoption within the hospitality industry.

Regarding cost factors, the study found a negative but statistically significant relationship between cost factors and open innovation adoption $(\beta=-0.589, t$-value $=17.503, \rho<0.000)$. This suggests that in spite of the important roles SMEs play, their development is largely constrained by a number of factors, such as lack of access to appropriate technology; lack of management skills and training; and most importantly, access to finance which negatively impacts on their ability to expand. This is consistent with previous findings and Abor and Quartey (2010) who have reported that one central issue fronting SMEs in their quest to innovate is the lack of resources. For SMEs operating in the hospitality sector to carry out their open innovation activities within their chronic resource-constrained environment, hospitality SME managers need to have the ability to think creatively, innovatively, critically and independently and to connect with financial institutions in order to benefit from relationship lending.

On cultural factors, the study found negative and statistically significant relationship between culture and open innovation adoption $(\beta=-0.628, t$-value $=10.699, \rho<0.000)$. The finding supports the work of Kaasa and Vadi (2010) who found negative relationship between culture and innovation. In a similar fashion, Yaveroglu and Donthu (2002) found a negative relationship between power distance and consumers' intention to innovate in a study that set to determine diffusion of consumer products in 19 wealthier nations. Again, Mitchell et al. (2000) found high power distance as a cultural dimension to have negative effect on business creation processes.

The results also revealed that there was a positive significant relationship between human skills and open innovation adoption $(\beta=0.697, t$-value $=14.170, \rho<0.000)$. This finding is in harmony with Delone and McLean (2003) who posit that, the success of implementing innovation is predicated on human resource 
factors. On their part, Bogers et al. (2018) found that firms with a diverse human capital pool have competitive edge in terms of engaging in open innovation. Furthermore, Lindegaard (2010) found that open innovation adoption depends on certain personal skills such as optimism, passion, drive, curiosity and the belief that change can be good. This suggests that, human skills in the adoption of open innovation is crucial because innovation process is spearheaded by people.

IT infrastructure is found to have direct and positive relationship with open innovation adoption $(\beta=0.131$, $t$-value $=2.721, \rho<0.007)$. This finding resonates with the study by Mihalic and Buhalis (2013) who postulated that ICT is a supporter of innovation (open and close) in the hospitality industry. Similarly, Christensen and Maskell (2003) contend that ICT has helped in the shift toward more open, collaborative and network-centered innovation practices. Moreover, the study also resonates with previous study by Faems et al. (2010) who found that technology alliance portfolio diversity has a positive impact on internal innovation efforts, which increases product innovation performance. IT infrastructure has a major relationship with open innovation adoption and is widely accepted by innovation scholars as a key determinant influencing open innovation. Also, managerial style was found to positively influence open innovation adoption $(\beta=0.629, t$-value $=19.567, \rho<0.000)$. This finding is in tandem with that of Simpson and Dansereau (2007) who argued that adoption of innovation depends heavily on management and leadership styles, employee empowerment and organizational climate that promotes innovation (open and close). The findings support the earlier work of Becan et al. (2012) who studied the innovation adoption as facilitated by a change-oriented workplace and found that the tendency to adopt workshop-based interventions is contingent on innovative firm with creative leadership and change-oriented workforce attributes such as professional growth, efficacy, adaptability and influence on others.

On their part, Scherp, Mezaris, et al. (2017) concluded that leadership is required for opening the innovation process and foster open innovation continuously beyond the phase of its introduction. Overall the findings from the study indicate that competition, human skills, managerial style and IT infrastructure are the main driving forces of open innovation adoption in the hospitality industry. However, cost and cultural factors had negative but significant influence on open innovation adoption.

\section{Theoretical Implication}

Open innovation has become a central issue to both managers and researchers over the last two decades. The current study thus, contributes to synthesizing the different views on open innovation adoption in the small and medium size enterprises (SMEs) operating in the hospitality industry and therefore, adds to the stream of studies undertaken to streamline the open innovation in a context which has seen small number of research on the subject as there are no set of generally accepted factors influencing the adoption of open innovation in the hospitality SMEs (Biemans \& Griffin, 2018). This study shows that the effect of cultural factors on open innovation adoption could be context-specific and that cultural dimensions may directly or indirectly influence the adoption of open innovation.

The empirical literature has placed little emphasis on determining factors of open innovation in the hospitality industry which has the potential to affect SMEs performance in terms of collaborative effort and cost of operation. As knowledge becomes the key resource, open innovation needs to be embedded in an overall business strategy that explicitly acknowledges the potential use of external ideas, knowledge and technology in value creation. The empirical findings suggest that developing state of art IT infrastructure impact hugely to increase the ability of firms to work across diverse geographic and organizational boundaries and enables firms to possibly create a competitive edge in the current business environment. Hospitality SMEs with the needed investment are able to create value for both the customer and the firm, either directly or indirectly, depending on the cultural context.

\subsection{Practical implication}

Managers must place a lot more emphasis on the building and maintenance of valued relationships. Managers of hospitality SMEs should be encouraged to the building of stronger relationships within financial industry and their social networks. Thus, hospitality SME managers need to have the ability to think creatively, innovatively, critically and independently and to connect/network with financial institutions 
in order to benefit from relationship lending to carry out their open innovation activities within their chronic resource-constrained environment. Managers should therefore seek to cultivate relationships with a wide array of external stakeholders such as the government, knowledge and research institutions and firms with appropriate policies to ensure access to crucial information and resources. They should further promote the importance of trust and solidarity among network members by providing opportunities for social interactions and by striving for a shared vision.

A firm's training activities should focus not only on extending their employees' functional or specific technological knowledge and skills but also on developing their abilities to network, collaborate, and share information and knowledge. The government could promote open innovation by reducing taxes and tariffs in a competitive manner and address the challenge of infrastructural constraints as a matter of urgency. Managers must also improve their dynamic capabilities and absorptive capacities by creating regular programs for staff development, and making the necessary investments in the area of job training and benchmarking industry standards and business planning to enhance their performance.

\subsection{Conclusions}

The study sought to find out the determining factors of open innovation adoption in the Ghanaian hospitality industry. The findings reveal that competition, human skills, IT infrastructure and managerial style are very critical to hospitality SMEs open innovation adoption. The findings also reveal that cost factors and cultural factors have negative but significant relationship with open innovation adoption.

\subsection{Limitation and Future Research}

The study was conducted in the hospitality SMEs sub-sector in Ghana and there should be caution in the interpretation of the results. There could be extension of the research to include other sectors of the economy. Again, replication of the research in other geographical locations would provide confirmation for the research findings. Future studies should investigate the relationship between culture and open innovation moderating role of gender and education. Future studies should include network capabilities and organizational learning to access their impacts on firm performance.

\section{Reference}

[1] Abor, J., \& Quartey, P. (2010). Issues in SME development in Ghana and South Africa. 39(6), 215228.

[2] Adomako, S. (2018). The moderating effects of adaptive and intellectual resource capabilities on the relationship between entrepreneurial orientation and financial performance. 22(03), 1850026.

[3] Ahn, J. M., Minshall, T., \& Mortara, L. (2017). Understanding the human side of openness: the fit between open innovation modes and CEO characteristics. 47(5), 727-740.

[4] Atuahene-Gima, K. (1996). The influence of innovation orientation in human resource management on new product development: The moderating role of innovation type. 1(1), 87-107.

[5] Autio, E., Pathak, S., \& Wennberg, K. (2013). Consequences of cultural practices for entrepreneurial behaviors. 44(4), 334-362.

[6] Becan, J. E., Knight, D. K., \& Flynn, P. M. (2012). Innovation adoption as facilitated by a changeoriented workplace. 42(2), 179-190.

[7] Biemans, W., \& Griffin, A. (2018). Innovation practices of B2B manufacturers and service providers: Are they really different? , 75, 112-124.

[8] Blundell, R., Griffith, R., \& Van Reenen, J. (1999). Market share, market value and innovation in a panel of British manufacturing firms. 66(3), 529-554.

[9] Bogers, M., Foss, N. J., \& Lyngsie, J. (2018). The "human side" of open innovation: The role of employee diversity in firm-level openness. 47(1), 218-231.

[10] Boso, N., Story, V. M., \& Cadogan, J. (2013). Entrepreneurial orientation, market orientation, network ties, and performance: Study of entrepreneurial firms in a developing economy. 28(6), 708727.

[11] Bossink, B. A. (2007). Leadership for sustainable innovation. 6(2), 135-149. 
[12] Chen, C.-P., Hu, J.-L., \& Yang, C.-H. (2011). An international comparison of R\&D efficiency of multiple innovative outputs: The role of the national innovation system. 13(3), 341-360.

[13] Chesbrough, H. (2003). The logic of open innovation: managing intellectual property. 45(3), 33-58.

[14] Chesbrough, H., \& Crowther, A. K. (2006). Beyond high tech: early adopters of open innovation in other industries. 36(3), 229-236.

[15] Chesbrough, H., Vanhaverbeke, W., \& West, J. (2006). Open innovation: Researching a new paradigm: Oxford University Press on Demand.

[16] Christensen, J. F., \& Maskell, P. (2003). The industrial dynamics of the new digital economy: Edward Elgar Publishing.

[17] Das, K. (2009). Relationship marketing research (1994-2006) An academic literature review and classification. 27(3), 326-363.

[18] Delone, W. H., \& McLean, E. R. (2003). The DeLone and McLean model of information systems success: a ten-year update. 19(4), 9-30.

[19] Denti, L., \& Hemlin, S. (2012). Leadership and innovation in organizations: A systematic review of factors that mediate or moderate the relationship. 16(03), 1240007.

[20] Elenkov, D. S., Judge, W., \& Wright, P. (2005). Strategic leadership and executive innovation influence: an international multi-cluster comparative study. 26(7), 665-682.

[21] Eseonu, C., \& Egbue, O. (2014). Socio-cultural influences on technology adoption and sustainable development. Paper presented at the Proceedings of the Industrial and Systems Engineering Research Conference, Montreal, QC, Canada.

[22] Faems, D., De Visser, M., Andries, P., \& Van Looy, B. (2010). Technology alliance portfolios and financial performance: value-enhancing and cost-increasing effects of open innovation. 27(6), 785796.

[23] Falk, R. F., \& Miller, N. B. (1992). A primer for soft modeling: University of Akron Press.

[24] Franzo, S. (2017). The role of organizational culture in open innovation adoption: the case of the energy efficiency sector.

[25] Gerguri, S., \& Ramadani, V. (2010). The impact of innovation into the economic growth.

[26] Ghana Statistical Service, G. ( 2013). Ghana Statistical Yearbook.

[27] Ghana Tourism Authority, G. (2010). Tourism Information on Ghana.

[28] Ghana Tourism Authority, G. (2016). Tourism Information on Ghana.

[29] Gilley, A., Dixon, P., \& Gilley, J. W. (2008). Characteristics of leadership effectiveness: Implementing change and driving innovation in organizations. 19(2), 153-169.

[30] Goedhuys, M., \& Sleuwaegen, L. (2010). High-growth entrepreneurial firms in Africa: a quantile regression approach. 34(1), 31-51.

[31] Haenlein, M., \& Kaplan, A. M. (2004). A beginner's guide to partial least squares analysis. 3(4), 283297.

[32] Hair, J. F., Ringle, C. M., \& Sarstedt, M. (2011). PLS-SEM: Indeed a silver bullet. 19(2), 139-152.

[33] Hair Jr, J., Sarstedt, M., Hopkins, L., \& Kuppelwieser, V. (2014). Partial least squares structural equation modeling (PLS-SEM) An emerging tool in business research. 26(2), 106-121.

[34] Herbig, P., \& Dunphy, S. (1998). Culture and innovation. 5(4), 13-21.

[35] Herzog, P. (2011). Open and closed innovation: Different cultures for different strategies: Springer Science \& Business Media.

[36] Hinson, R., \& Sorensen, O. (2006). E-business and small Ghanaian exporters: Preliminary micro firm explorations in the light of a digital divide. 30(2), 116-138.

[37] Hofstede, G. (2001). Culture's consequences: Comparing values, behaviors, institutions and organizations across nations: Sage publications.

[38] Hulland, J. (1999). Use of partial least squares (PLS) in strategic management research: a review of four recent studies. 20(2), 195-204.

[39] Inauen, M., \& Schenker-Wicki, A. (2012). Fostering radical innovations with open innovation. 15(2), 212-231.

[40] Jumia Travel, J. (2019). Hospitality Report Ghana 2016.

[41] Kaasa, A., \& Vadi, M. (2010). How does culture contribute to innovation? Evidence from European countries. 19(7), 583-604. 
[42] Kankam, A. W. (2015). Factors Influencing Social Media Utilization as a Communication Tool in the Ghanaian Hotel Industry. University of Ghana,

[43] Kerr, S., \& Newell, R. G. (2003). Policy-induced technology adoption: evidence from the US lead phasedown. 51(3), 317-343.

[44] Laursen, K., \& Foss, N. J. (2003). New human resource management practices, complementarities and the impact on innovation performance. 27(2), 243-263.

[45] Lichtenthaler, U. (2011). Open innovation: Past research, current debates, and future directions. 25(1), 75-93.

[46] Lindegaard, S. (2010). The open innovation revolution: essentials, roadblocks, and leadership skills: John Wiley \& Sons.

[47] Magner, N., Welker, R. B., \& Campbell, T. L. (1996). Testing a model of cognitive budgetary participation processes in a latent variable structural equations framework. 27(1), 41-50.

[48] Manual, O. (2005). The Measurement of Scientific and Technological Activities. Guidelines for collecting and interpreting innovation data. In: Paris: OECD, Eurostat.

[49] Mazur, J., \& Zaborek, P. (2016). Organizational culture and open innovation performance in small and medium-sized enterprises (SMEs) in Poland. 51(1), 104-138.

[50] Mensah, I. (2006). Environmental management practices among hotels in the greater Accra region. 25(3), 414-431.

[51] Mihalic, T., \& Buhalis, D. (2013). ICT as a new competitive advantage factor-Case of small transitional hotel sector. 15(1), 33.

[52] Mitchell, R. K., Smith, B., Seawright, K. W., \& Morse, E. A. (2000). Cross-cultural cognitions and the venture creation decision. 43(5), 974-993.

[53] Moen, Ø., Tvedten, T., \& Wold, A. (2018). Exploring the relationship between competition and innovation in Norwegian SMEs. 5(1), 1564167.

[54] Morgan, G. A., Leech, N. L., Gloeckner, G. W., \& Barrett, K. C. (2004). SPSS for introductory statistics: Use and interpretation: Psychology Press.

[55] Mumford, M. D., Antes, A. L., Caughron, J. J., \& Friedrich, T. L. (2008). Charismatic, ideological, and pragmatic leadership: Multi-level influences on emergence and performance. 19(2), 144-160.

[56] Namasivayam, K., Enz, C. A., \& Siguaw, J. A. (2000). How wired are we? Selection and use of new technology in US hotels. 41(6), 40-48.

[57] Naqshbandi, M. M., Kaur, S., \& Ma, P. (2015). What organizational culture types enable and retard open innovation? , 49(5), 2123-2144.

[58] Narteh, B., Agbemabiese, G. C., Kodua, P., \& Braimah, M. (2013). Relationship marketing and customer loyalty: Evidence from the Ghanaian luxury hotel industry. 22(4), 407-436.

[59] Närvänen, R. (2018). Transformational, Transactional or just laissez-faire? Leadership, Change, and Digitalization in the.

[60] Nguyen, V., Van Ness, B. F., \& Van Ness, R. R. (2007). Inter-market competition for exchange traded funds. 31(2), 251-267.

[61] Nicita, A., Ramello, G. B., \& Scherer, F. M. (2005). Intellectual property rights and the organization of industries: new perspectives in law and economics. 12(3), 289-296.

[62] Nickell, S. J. (1996). Competition and corporate performance. 104(4), 724-746.

[63] Nieto, M. J., \& Santamaría, L. J. J. o. S. B. M. (2010). Technological collaboration: Bridging the innovation gap between small and large firms. 48(1), 44-69.

[64] OECD. (2008). Globalization and Open Innovation. (OECD, Paris.).

[65] OECD. (2015). OECD Digital Economy Outlook 2015.

[66] OECD. (2017). Enhancing the Contributions of SMEs in a Global and Digitalised Economy. Paper presented at the Meeting of the OECD Council at Ministerial Level, Paris.

[67] Orosz, G., Tóth-Király, I., Büki, N., Ivaskevics, K., Bőthe, B., \& Fülöp, M. (2018). The Four Faces of Competition: The Development of the Multidimensional Competitive Orientation Inventory. 9.

[68] Oxford Business Group, G. (2019). Ghanaian tourism grows with increased visitors and new funding strategies.

[69] Page, A. L., \& Schirr, G. R. (2008). Growth and development of a body of knowledge: 16 years of new product development research, 1989-2004. 25(3), 233-248.

[70] Pavitt, K. (2003). The process of innovation (Vol. 89): SPRU Brighton. 
[71] Porter, M. E., Michael, \& Gibbs, i. (2001). Strategy and the Internet.

[72] Ringle, C. M., Wende, S., \& Becker, J.-M. (2015). SmartPLS 3 Boenningstedt: SmartPLS GmbH, http://www. smartpls. com.

[73] Santamaría, L., Nieto, M. J., \& Miles, I. (2012). Service innovation in manufacturing firms: Evidence from Spain. 32(2), 144-155.

[74] Santarelli, E., \& Sterlacchini, A. (1990). Innovation, formal vs. informal R\&D, and firm size: Some evidence from Italian manufacturing firms. 2(3), 223-228.

[75] Schein, E. H. (1992). How can organizations learn faster?: the problem of entering the Green Room.

[76] Scherp, A., Mezaris, V., Köhler, T., \& Hauptmann, A. (2017). MultiEdTech 2017: 1st international workshop on multimedia-based educational and knowledge technologies for personalized and social online training. Paper presented at the Proceedings of the 25th ACM international conference on Multimedia.

[77] Scherp, A., Pscheida, D., Wiese, M., Nishioka, C., Köhler, T., Maas, A., . . Mezaris, V. (2017). MOVING: Training Towards a Society of Data-savvy Information Professionals.

[78] Shane, S. (1993). Cultural influences on national rates of innovation. 8(1), 59-73.

[79] Simpson, D. D., \& Dansereau, D. F. (2007). Assessing organizational functioning as a step toward innovation. 3(2), 20.

[80] Sirirak, S., Islam, N., Ba Khang, D. J. J. o. H., \& Technology, T. (2011). Does ICT adoption enhance hotel performance? , 2(1), 34-49.

[81] Statistics Norway, S. (2012). Innovation costs in the Norwegian survey on

[82] R\&D and innovation.

[83] Storey, D. J., Keasey, K., Watson, R., \& Wynarczyk, P. (2016). The performance of small firms: profits, jobs and failures: Routledge.

[84] Swart, K. W. (2013). The sense of decadence in nineteenth-century France (Vol. 7): Springer Science \& Business Media.

[85] Tian, M., Deng, P., Zhang, Y., \& Salmador, M. P. (2018). How does culture influence innovation? A systematic literature review. 56(5), 1088-1107.

[86] Tsai, H., Song, H., \& Wong, K. K. (2009). Tourism and hotel competitiveness research. 26(5-6), 522-546.

[87] Tsai, K.-H., \& Yang, S.-Y. (2014). The contingent value of firm innovativeness for business performance under environmental turbulence. 10(2), 343-366.

[88] Van der Meer, H. (2007). Open innovation-the Dutch treat: challenges in thinking in business models. 16(2), 192-202.

[89] West, J., \& Gallagher, S. (2006). Challenges of open innovation: the paradox of firm investment in open-source software. 36(3), 319-331.

[90] Williams, L., \& McGuire, S. (2005). Effects of national culture on economic creativity and innovation implementation. 3(1), 31-40.

[91] Wong, K. K.-K. (2013). Partial least squares structural equation modeling (PLS-SEM) techniques using SmartPLS. 24(1), 1-32.

[92] World Bank, T. D. (2018). The World Bank Tourism Development Project P164211.

[93] Xuhua, H., Spio-Kwofie, A., Udimal, T. B., \& Addai, M. (2018). Entrepreneurial innovation strategies; an option for small hotels' growth in Ghana. 8(1), 30.

[94] Yaveroglu, I. S., \& Donthu, N. (2002). Cultural influences on the diffusion of new products. 14(4), 49-63.

[95] Yukl, G., \& Mahsud, R. (2010). Why flexible and adaptive leadership is essential. 62(2), 81.

[96] Yun, J. J., Park, K., Kim, J., \& Yang, J. (2016). Open innovation effort, entrepreneurship orientation and their synergies onto innovation performance in SMEs of Korea. 21(3), 366-390.

[97] Zhang, A., Zhang, C., Fu, G., Wang, B., Bao, Z., \& Zheng, H. (2012). Assessments of impacts of climate change and human activities on runoff with SWAT for the Huifa River Basin, Northeast China. 26(8), 2199-2217.

[98] Zopiatis, A., \& Theocharous, A. L. (2018). PRAXIS: The determining element of innovation behavior in the hospitality industry. 35, 9-16. 